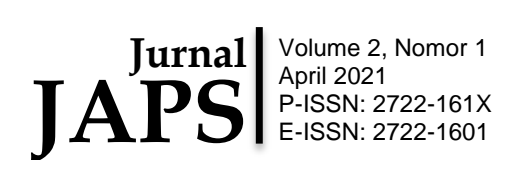

DOI: $10.46730 /$ japs.v2i1.15

\title{
Inkonsistensi Tentang Pemberhentian Kepala Negara Menurut Konstitusi Indonesia
}

\author{
Aryo Akbar ${ }^{1}$ \\ ${ }^{1}$ Fakultas Hukum, Universitas Islam Riau. \\ Email : aryoakbar@law.uir.ac.id
}

\begin{abstract}
Kata kunci
Abstrak

Tujuan dari penelitian, Untuk Menganalisis Tentang Pemberhentian Kepala Negara Menurut konstitusi,Untuk Mengetahui Idealnya Bentuk Idealnya Pengaturan Tentang Pemberhentian Kepala Negara Berdasarkan Konstitusi. penelitian ini termasuk dalam penelitian hukum normatif yakni penelitian yang berdasarkan buku atau kepustakaan untuk mengkaji dan meneliti terhadap penelitian yang akan dilakukan. Hasil penelitian ini Hendaknya perlu dilakaukan legislatif review mengenai amandemen terhadap konstitusi guna memberikan kekuatan hukum mengenai putusan Mahkamah Konstitusi terhadap pemberhentian Presiden dan/atau Wakil.
\end{abstract}

Keywords

Hukum, Kontitusi,

Kepala Negara

\begin{abstract}
The purpose of the research is to analyze the dismissal of the head of state according to the constitution, to find out the ideal form of the ideal arrangement for the dismissal of the head of state based on the constitution. This research is included in normative legal research, namely research based on books or literature to study and research the research that will be carried out. The results of this research. Legislative review of the amendments to the constitution should be carried out in order to provide legal force regarding the decision of the Constitutional Court on the dismissal of the President and / or Deputy.
\end{abstract}

\section{Pendahuluan}

Sebuah bangsa saat melaksanakan demokrasi untuk menggerakkan roda kekuasaan. Menyebabkan orang yang menjadi peminpin guna menjalankan kekuasaan dalam negara tersebut harus berdasarkan dari keinginan rakyat dalam negara tersebut. Hal tersebut juga terjadi terhadap seorang Presiden yang dipilih oleh rakyat. Presiden adalah orang yang diberikan kewenanagan dalam menjalankan roda pemerintahan berdasarkan keinginan rakyat. Kewenangan dalam menjalankan roda pemerintahan ini diberikan pada bidang eksekutif. (Bagir Manan, 2005: hlm. 33) 
Menurut Soewoto Mulyusudarmo setiap kekuasaan yang dijalankan oleh Presiden harus dipertanggungjawabkan penyelengaraan negara yang dijalankannya kepada Parlemen yakni lembaga eksekutif dan MPR. Ini disebabkan karena tidak ada kekuasaan dalam suatu bangsa menggunakan pemerintahan yang demokrasi tanpa pertanggungjawaban saat menyelenggarakan pemerintahan. Sehingga setiap system pemerintahan yang dijalankan oleh kelola negara harus dipertanggungjawabankan kepada pihak parlemen yang memiliki kewenangan dalam melakukan pengawasan terhadap kinerja kepala negara dalam menjalankan roda pemerintahan. (Soewoto Mulyusudarmo, 199: hlm. 1-2)

Mekanisme dalam pemberhentian kepala negara yang masih memiliki waktu untuk menjalankan roda pemerintahan sebelum dilakukan amandemen terhadap konstitusi belum diatur secara tegas serta jelas terhadap pemberhentian kepala negara. Namun, setelah dilakukan amandemen yang ketiga terhadap konstitusi mekanisme dalam pemberhentian kepala negara Indonesia pada Pasal 7A dan 7B. Terhadap kewenangan pemberhentian Presiden juga melibatkan lembaga peradilan yakni Mahkamah Konsitusi berdasarkan Pasal 24C ayat (2) konstitusi Indonesia. (Abdul Muktie Fadjar, 2006: hlm. 29)

Sehingga Mahkamah Konstitusi harus memeriksa pendapat DPR mengenai indikasi pelanggaran hukum yang terjadi sebagaimana yang diatur dalam konstitusi mengenai alasan-alasan yang dapat dijadikan untuk dilakukan pemberhentian terhadap kepala negara. (Abdul Muktie Fadjar, 2006: hlm. 31)

Setelah dilakukan pemeriksaan oleh Mahkamah Konstitusi maka akan dituangkan dalam bentuk putusan hukum. Setelah Mahkamah Konstitusi memutuskan pendapat DPR selanjutnya Dewan Perwakilan Rakyat akan menyampaikan pada Majelis Permusyawaratan Rakyat untuk mengadakan sidang istimewa dengan agenda pemberhentian Presiden. Hal ini disebabkan karena MPR adalah pihak yang memiliki kewenangan dalam melakukan pengangkatan serta pemberhentian Presiden.

Setelah Mahkamah Konstitusi memutuskan pendapat DPR selanjutnya putusan tersebut akan diberikan kembali pada DPR, DPR akan memberikan pada Majelis Permusyawaratan Rakyat yang selanjutnyan akan dibawa saat sidang Paripurna Majelis Permusyawaratan Rakyat untuk memutuskan nasib Presiden diberhentikan atau tetap menjalankan system pemerintahan. seringkali keputusan diambil nantinya melalui voting (suara terbanyak). Jadi pemberhentian Presiden tidak lepas dari unsur politik dalam menjalankan roda pemerintahan.

Adapun ketentuan yang telah diatur berdasarkan ketentuan Pasal 7A kostitusi menyangkut alasan-alasan pemberhentian kepala negara. Sedangkan ketentuan Pasal 7B konstitusi adalah mengenai proses pemberhentian terhadap kepala negara yang masih memegang kekuasaan untuk menyelenggarakan negara. Jadi, dilakukan amandemen adalah untuk dilakukannya pengaturan mengenai pemberhentian kepala negara telah ada pada konstitusi Indonesia ini menginginkan dalam pemberhentian kepala negara tidak dilakukan sewenang-wenang oleh parlemen. (Abdul Muktie Fadjar, 2006: hlm. 35) 
Menurut Saldi Isra menyatakan "apapun bentuk kesalahan yang telah dilakukan Presiden/Wakil Presiden dapat menjadi celah dalam melaksanakan pemberhentian. Ini terjadi berdasarkan pendapat DPR dalam memberikan pendangan mengenai ketentuan pada Pasal 7A Undang-Undang Dasar Negara Republik Indonesia Tahun 1945 mengenai apa alasan dalam melakukan pemberhentian Presiden walaupun belum habis masa jabatannya”. (Saldi Isra, Gerbang Menuju Pemakzulan, Media Indonesia, Rabu 04 November 2009)

Bila suatu negara koalisi yang di bangun diparlemen sangat besar maka sangat susah untuk melakukan pemberhetian terhadap kepala negara dalam suatu negara. Menurut Penulis kepastian hukum mengenai putusan yang diberikan Mahkamah Konstitusi tidak memiliki kekuatan apa-apa karena akan dibawa pada rapat MPR. Sehingga diputus Mahkamah Konstitusi seharusnya dijalankan oleh pihak Majelis Permusyawaratan Rakyat. Namun faktanya bila diparlemen dukungan terhadap Presiden cukup besar, maka untuk memberhentikan Presiden dalam masa jabatannya akan sulit untuk dilakukan karena dukungan politik sangat berpengaruh dalam pengambilan keputusan.

Namun putusan yang dibuat Mahkamah Konstitusi tidak secara langsung dilaksanakan sebab putusan yang dibuat oleh Mahkamah Konstitusi tersebut diberikan kepada Dewan Perwakilan Rakyat yang bertujuan bagi parlemen dalam memutuskan apakah Presiden diberhentikan atau tidak diberhentikan sebagai orang yang diberikan kewenangan berdasarkan pilihan rakyat untuk menjalankan roda pemerintahan dengan masa jabatan 5 (lima) tahun.

Sebelum perubahan terhadap konstitusi Indonesia proses pemberhentian pemberhentian terhadap kepala Negara adalah tergantung diterima atau tidaknya laporan pertanggungjawaban yang diberikan dan dibacakan dalam sidang istimewa MPR. Pada sistem ketatanegaraan Indonesia proses pemberhentian kepala negara yang dilakukan oleh Majelis Permusyawaratan Rakyat terhadap Presiden yang masih menjalankan kekuasaan pernah ada terhadap 2 (dua) orang yang memimpin Indonesia yakni pada masa Presiden Soekarno yang tidak diterima laporan pertanggungjawabannya oleh Majelis Permusyawaratan Rakyat. laporan pertanggungjawaban yang diberikan oleh Soekarno dalam sidang istimewa tidak dapat diterima oleh pihak parlemen, sehingga mengakibatkan dilakukan pemberhentian terhadap dirinya.

Pada masa Presiden Abdurrahman Wahid yang tidak menghadiri sidang istimewa guna memberikan laporan pertanggungjawabannya kepada Majelis Permusyawaratan Rakyat. Saat itu Presiden Abdurahhman Wahid tidak melakukan penyampaian laporan pertanggungjawaban yang diminta oleh Majelis Permusyawaratan Rakyat serta tidak hadir dalam sidang istimewa yang dilaksanakan Majelis Permusyawaratan Rakyat. Akhirnya Majelis Permusyawaratan Rakyat mengeluarkan ketetapan pemberhentian Abdurrahman Wahid sebagai Presiden karena ketidakhadirannya untuk memberikan laporan pertanggungjawabannya pada Majelis Permusyawaratan Rakyat. ( Firmansyah Arifin Dkk, 2005: hlm. 45-46) 


\section{Metode Penelitian}

Berdasarkan jenisnya, penelitian ini termasuk dalam penelitian hukum normatif yakni penelitian yang berdasarkan buku atau kepustakaan untuk mengkaji dan meneliti terhadap penelitian yang akan dilakukan. Fokus dalam penelitian ini adalah pada pemberhentian kepala negara dalam konstitusi Indonesia. Soerjono Soekanto dan Sri Mamudji, 2007: hlm. 13-14)

\section{Hasil Dan Pembahasan}

\section{Pengaturan Pemberhentian Kepala Negara Berdasarkan Konstitusi}

Penerapan model pemberhentian kepala negara ini mengalami perubahan setelah dilakukannya amandemen pada konstitusi Indonesia. Pasca perubahan yang dilakukan dalam konstitusi mekanisme mengenai pemberhentian kepala negara tidak hanya melibatkan lembaga perwakilan rakyat, Mahkamah Konstitusi masuk sebagai lembaga peradilan yang memiliki kewenangan untuk memberikan putusan terhadap Presiden yang disampaikan oleh pihak DPR. ( Sjachran Basah, 1981: hlm. 39)

Menurut Abdul Mukthie Fadjar menyatakan penerapan system pemerintahan yang Presidensial memiliki dampak mengenai adanya pemberhentian terhadap kepala negara yang dilakukan oleh lembaga parlemen. Dalam melakukan pemberhentian terhadap kepala negara perlu diatur pada konstitusi. (Abdul Mukthie Fadjar, 2006: hlm. 240)

Proses pemberhentian Presiden harus berdasarkan ketentuan yang telah diatur pada konstitusi Indoneesia. Untuk menghindari terjadinya kesalahan pada proses pemberhentian Presiden mengingat Presiden dipilih melalui sistem demokrasi.

Berdasarkan Pasal 7A dan 7B Undang-konstitusi Indonesia berisi tentang pemberhentian kepala negara. Pemberhentian Presiden berdasarkan usulan dari pendapat Dewan Perwakilan Rakyat harus meminta pendapat pada lembaga peradilan untuk memutuskan pendapat DPR.

Pengajuan usulan dari pihak Legislatif Kepada Mahkamah Konstitusi adalah salah satu bentuk keseimbangan antara Presiden dengan Dewan Perwakilan Rakyat. hal ini menyebakan kedua lembaga negara negara ini untuk menciptakan proses check and balance pada lembaga negara. DPR harus meminta putusan kepada Mahkamah Konstitusi terlebih dahulu.

Dewan Perwakilan Rakyat harus akan meminta pendapat Mahkamah Konstitusi sebagai dalam memutuskan mengenai dugaan pelanggaran hukum. Hasil putusan Mahkamah Konstitusi selanjutnya akan menjadi alasan oleh Dewan Perwakilan Rakyat untuk menyampaikan usulan agar dilaksanakannya sidang istimewa guna menentukan masa jabatan Presiden.

Dukungan politik di parlemen sangat berpengaruh dalam pengambilan putusan mengenai pemberhentian terhadap kepala negara. Dukungan politik lebih berpengaruh dibandingkan putusan yang diberikan oleh mahkamah konstitusi terhadap pelanggaran hukum yang dilakukan kepala negara dalam menjalankan roda pemerintahan yang 
dibuktikan melalui pemeriksaan yang dilakukan Mahkamah Konstitusi dan dituangkan dalam bentuk putusan.

Penulis berpendapat bahwa perubahan konstitusi dianggap perlu guna memperbaiki mengenai pengaturan pemberhentian kepala negara. Perlu juga dilakukan penguatan terhadap sistem Presidensial dalam konstitusi. Menurut Penulis pengaturan mengenai pemberhentian Presiden setelah dilakukannya perubahan terhadap konstitusi telah jelas diatur. Berdasarkan konstitusi mengenai alasan pemberhentian Presiden diatur dalam Pasal 7A serta mekanisme pemberhentian Presiden telah ada di Pasal 7B.

Pengaturan yang mengatur mengenai pemberhentian kepala negara baru mulai diatur seteleh dilakukan amandemen terhadap konstitusi. Sebelum dilakukan amandemen pemberhentian kepala negara hanya berdasarkan laporan pertanggungjawaban yang dibarikan kepada pihak parlemen saat sidang istimewa. Jika laporan yang diberikan tersebut bisa diterima oleh pihak parlemen maka Presiden tidak akan diberhentikan dan akan terus menjalankan roda pemerintahan dalam menyelenggarakan negara. Namun, bila laporan pertanggungjawaban yang diberikan tidak dapat diterima oleh pihak parlemen maka ada kemungkinan Presiden akan diberhentikan.

Namun, alasan yuridis semata tidak dapat diputus langsung untuk dilakukannya pemberhentian terhadap kepala negara. Alasan yuridis hanya merupakan alasan yang dijadikan dasar dalam melakukan pemberhentian kepala negara. Maka selanjutnya Dewan Perwakilan Presiden akan meminta lembaga pengadilan untuk memutuskannya. Adapun kewenangan menjadi kewajiban dari lembaga Mahkamah Konstitusi untuk memutuskan pendapat DPR berdasarkan alasan yuridis yang diberikan kepada Mahkamah Konstitusi mengenai kesalahan yang telah dilakukan Presiden.

\section{Idealnya Pengaturan Tentang Pemberhentian Kepala Negara Berdasarkan Konstitusi}

Selanjutnya Pasal 7A menguraikan apa yang menjadi alasan-alasan dalam pemberhentian kepala negara dalam masa jabatannya, selanjutnya Pasal 7B UndangUndang Dasar Negara Republik Indonesia Tahun 1945 Indonesia menguraikan mekanisme pemberhentian Presiden dan/atau Wakil Presiden dalam masa jabatannya. Kewenangan yang dimiliki oleh Mahkamah Konstitusi. (Refly Harun, Zainal A.M. Husein, dan Bisariyadi, 2004: hlm 77)

Tidak ada ketentuan dalam konstitusi mewajibkan MPR untuk melakukan putusan yang telah dilakukan lembaga mahkamah konstitusi mengenai pemberhentian terhadap kepala negara tidak memiliki akibat hukum atau sanksi sehingga tidak dilaksanakannya putusan yang dibuat Mahkamah Konstitusi akan menimbulkan ketidakpastian hukum bila tidak dilaksanakan oleh Majelis Permusyawaratan Rakyat selaku eksekutor dari putusan Mahkamah Konstitusi.

Idealnya seharusnya putusan yang dibuat atau dikeluarkan oleh Mahkamah Konstitusi harus segera dijalankan dengan dibawa kesidang istimewa guna menjalankan putusan Mahkamah Konstitusi tanpa melakukan voting lagi. Bila voting dilakukan 
otomatis jika suara terbanyak tidak menerima putusan yang dibuat Mahkamah Konstitusi.

Tidak dijalankannya putusan yang dibuat oleh Mahkamah Konstitusi jelas telah melanggar ketentuan yang terdapat dalam Pasal 1 Ayat 1 Undang-Undang Dasar Negara Republik Indonesia Tahun 1945 yang menyatakan bahwa "negara Indonesia adalah negara Hukum". Salah satu unsur dari negara hukum adalah adanya Supremacy Hukum (Penegakan Hukum).

Pemberian keputusan dilakukan Majelis Permusyawaratan rakyat harus sesuai dengan konstitusi. (Maruarar Siahaan, 2011: hlm. 77)

Mahkamah Konstitusi dalam memberikan putusan mengenai pemberhentian kepala negara tidaklah final. Hal ini disebabkan putusan yang diberikan oleh Mahkamah Konstitusi bisa dianulir oleh Majelis Permusyawaratan Rakyat. Hal ini tergantung suara mayoritas diparlemen. (Abdul Latif, 2007: hlm. 164)

Idealnya dalam konstitusi putusan yang telah dibuat oleh Mahkamah Konstitusi harus langsung dilakukan Majelis Permusyawaratan Rakyat saat sidang istimewa. Sebab kewenangan untuk mengangkat dan memberhentikan Presiden berdasarkan konstitusi.

Ini disebabkan bila putusan yang telah dibuat oleh Mahkamah Konsitusi tidak dilaksanakan disebabkan suasana politik diparlemen. Maka hal tersebut jelas tidak memberikan kepastian hukum dalam putusan yang telah dibuat ${ }^{1}$

Pada konsep negara hukum yang terdapat pada konstitusi. Terdapatnya penegakan hukum dan tersedianya peradilan adminitrasi negara merupakan konsep negara hukum. Dalam proses impeachment. Ini bertujuan dalam proses pemberhentian Presiden/Wakil Presiden tidak dilakukan secara sewenang-wenangan terhadap pemberhentian kepala negara yang masih memegang jabatannya dalam menjalankan roda pemerintahan.

Penulis berpendapat bahwa perubahan terhadap konstitusi dianggap perlu guna memperbaiki mengenai pengaturan pemberhentianPresiden dan Wakil Presiden. Perlu juga dilakukan penguatan terhadap sistem Presidensial dalam Konstitusi Indonesia. Selain itu proses pemberhentian kepala negara harus disesuaikan dalam sistem pemerintahan Presidensial menurut konstitusi.

\section{Kesimpulan}

Berikut kesimpulan dalam penelitian ini sebagai berikut:

1. Pengaturan Presiden dan/atau Wakil Presiden diatur di Pasal 7A dan 7B setelah dilakukan perubahan terhadap konstitusi.

2. Idealnya setelah putusan yang dibuat oleh Mahkamah Konstitusi dan diserahkan kepada Dewan Perwakilan Rakyat dan selanjutnya Dewan Perwakilan Rakyat mengusulkan kepada Majelis Perwakilan Rakyat untuk melaksanakan sidang Istimewa untuk melaksanakan putusan Mahkamah Konstitusi tanpa melakukan voting lagi.

\footnotetext{
${ }^{1} I b i d .,$. hlm. 59.
} 


\section{Daftar Pustaka}

Abdul Rasyid Thalib. 2006. Wewenang Mahkamah Konstitusi dan Implikasinya dalam Sistem Ketatanegaraan Republik Indonesia, Bandung: Citra Aditya Bakti.

Abdul Latif. 2007. Fungsi Mahkamah Konstitusi Dalam Upaya Mewujudkan Negara Hukum Demokrasi. Yogyakarta: Total Media.

Abdul Muktie Fadjar. 2006. Hukum Konstitusi \& Mahkamah Konstitusi. Jakarta: Konstitusi Press.

Abdul Ghoffar. 2009. Perbandingan Kekuasaan Presiden Indonesia Setelah Perubahan UUD 1945 dengan Delapan Negara Maju. Jakarta: Kencana.

Abdul Rasyid Thalib. 2006. Wewenang Mahkamah Konstitusi dan Implikasinya dalam Sistem Ketatanegaraan Republik Indonesia. Bandung: Citra Aditya Bakti.

Achmad Ali. 2002. Menguak Tabir Hukum (Suatu Kajian Filosofis dan Sosiologis), Jakarta: Gunung Agung.

Ahmad Syarizal. 2007. Peradilan Konstitusi Suatu Studi tentang Adjudifikasi Konstitusional Sebagai Mekanisme Penyelesaian Sengketa Normatif. Yogyakarta: Total Media.

Bagir Manan. 2006. Lembaga Kepresidenan, Cetakan Ketiga (Edisi revisi). Yogyakarta: FH UII Press.

Bagir Manan . 2005. DPR, DPD, dan MPR dalam UUD 1945 BARU. Yogyakarta: FH UII Press.

Cst Kansil, Christine , S.T Kansil, Engelien R, Palandeng dan Godlieb N Mamahit. 2009. Jakarta: Kamus Istilah Hukum.

Ellydar Chaidir. 2007. Hukum Dan Teori Konstitusi. Yogyakarta: Total Media.

Fatmawati. 2006. Hak Menguji (Toetsingsrecht) Yang Dimiliki Hakim Dalam Sistem Hukum Indonesia. Jakarta: Rajawali Press.

Firmansyah Arifin dkk. 2005. Lembaga Negara dan Sengketa Kewenangan Antarlembaga Negara. Jakarta: Konsorsium Reformasi Hukum Nasional.

Hamdan Zoelva. 2011. Pemakzulan Presiden di Indonesia. Jakarta: Sinar Grafika.

Hamdan Zoelva . 2005. Impeachment Presiden: Alasan Tindak Pidana Pemberhentian Presiden Menurut UUD 1945. Jakarta: Konstitusi Press.

Hans Kelsen. 2010. "General Theory of law and state". Bandung: Nusa Media.

Hans Kelsen . 2011. Teori Umum Tentang Negara dan Hukum, penerjemah: Raisul Muttaqien, Cet VI. Bandung: Nusa Media.

I Dewa Gede Atmadja. 2010. Hukum Konstitusi Problematika Konstitusi Indonesia Sesudah Perubahan UUD 1945. Malang: Setara Press.

Ibrahim R.. dkk (penyadur). 1995. Sistem Pemerintahan Parlementer dan Presidensial, Cetakan pertama. Jakarta: PT. RajaGrafindo Persada.

Ismail Suny. 1985. Pembagian Kekuasaan Negara. Jakarta: Aksara Baru.

Janedri M. Gaffar. 2012. Demokrasi Konstitusional Praktek Ketatanegaraan Indonesia Setelah Perubahan UUD 1945. Jakarta: Konpress.

Jazim Hamidi dan Mustafa Lutfi. 2010. Hukum Lembaga Kepresidenan Indonesia. Bandung: Alumni.

Jimly Asshiddiqie. 2010. Konstitutsi dan KonstitusionalismeIndonesia. Jakarta: Sinar Grafika.

Jimly Asshiddiqie. 2005. Hukum Tata Negara dan Pilar-Pilar Demokrasi, Cetakan Kedua. Jakarta:Konstitusi Press.

Jhon Pieris. 2007. Pembatasan Konstitusional Kekuasaan Presiden Republik Indonesia. Jakarta: Pelangi Cendikia. 
Juniarso Ridwan dan Achmad Sodik Sudrajat. 2010. Hukum Administrasi Negara dan Kebijakan Pelayanan Publik. Bandung: Nuansa.

M. Saleh dan Mukhlish. 2010. Impeachment Presiden dan/atau Wakil Presiden (Sebuah Tinjauan Konstitusional). (Surabaya: Bina Ilmu Offset.

Miriam Budiardjo. 1998. Dasar-Dasar Ilmu Politik. Jakarta: Gramedia Pustaka Utama.

Moh. Mahfud M.D. 2011. Perdebatan Hukum Tata Negara Pasca Amandemen Konstitusi. Jakarta: Rajawali Pers.

Moh. Kusnardi dan Harmaily Ibrahim. 1999. Hukum Tata Negara Indonesia, Jakarta: Pusat Studi Hukum Tata Negara Hukum UI dan CV. Sinar Bakti.

Munir Fuady. 2009. Konsep Negara Demokrasi. Jakarta: Retika Aditama.

Muhammad Yamin. 2002. Proklamasi dan Konstitusi Indonesia. Jakarta: Ghalia Indonesia.

Ni'matul Huda. 2007. Dalam Lembaga Negara Dalam Masa Transisi Demokrasi. Yogyakarta: UII Press.

Peter Mahmud Marzuki. 2008. Pengantar Ilmu Hukum. Jakarta: Kencana.

Philipus M. Hadjon. 1997. Tentang Wewenang. Yogyakarta: Yurika.

Refly Harun, Zainal A.M. Husein, dan Bisariyadi. 2004. Menjaga Denyut Konstitusi : Refleksi Satu Tahun Mahkamah Konstitusi. Jakarta: Konstitusi Press.

Saldi Isra. 2010. Pergeseran Fungsi Legislasi Menguatkan Model Legislasi Parlementer Dalam Sistem Presidensial Indonesia. Jakarta: Rajawali Press.

Syamsuddin Haris. 2007. Konflik Presiden-DPR dan Dilema Transisi Demokrasi di Indonesia. Jakarta: Grafiti.

Soerjono Soekanto dan Sri Mamudji. 2007. Penelitian Hukum Normatif Suatu Tindakan Singkat. Jakarta: Raja Grafindo.

Soehino. 2000. Ilmu Negara. Liberty: Yogyakarta.

Soimin dan Mashuriyanto. 2013. Mahkamah Konstitusi Dalam Sistem Ketatnegaraan Indonesia. Yogyakarta: UII Press.

Titik Triwulan Tutik. 2005. Konstruksi Hukum Tata Negara Indonesia Pasca Amandemen UUD 1945. Jakarta: Kencana Prenada Media Group.

\section{B. Jurnal/Makalah}

Ateng Syafrudin, Menuju Penyelenggaraan Pemerintahan Negara yang Bersih dan Bertanggung Jawab, Jurnal Pro Justisia Edisi IV,(Bandung: Universitas Parahyangan, 2000

Cora Elly Novianti, Demokrasi dan Sistem Pemerintahan, dalam Jurnal Konstitusi, Vol. 10, No. 2, Juni, Mahkamah Konstitusi, Jakarta, 2013

Rusadi Kantaprawira, Hukum dan Kekuasaan, Makalah, (Universitas Islam Indonesia: Yogyakarta, 1998

SoewotoMutyosudarmo, Pembaharuan Ketatanegaraan Melalui Perubahan Konstitusi, Assosiasi Pengajar HTN dan HAN Jawa Timur dan In-Trans, Malang, 2004

\section{Internet}

jurnalverstek.files.wordpress.com/2012 diakses pada hari senin tanggal 11 Agustus 2014

Saldi Isra, Gerbang Menuju Pemakzulan, tersedia di http://www.saldiisra.web.id/index.php?option=com_content $\&$ view=category $\& i d=$ $\underline{23 \& \text { Itemid }=11}$, diakses tanggal 12 November 20 